УДК 691.574:66.013

ИСПОЛЬЗОВАНИЕ ОТХОДОВ НЕФТЕХИМИЧЕСКОГО

ПРОИЗВОДСТВА И НЕФТЕДОБЫЧИ В ПРОИЗВОДСТВЕ

СЕЙСМОСТОЙКОГО КИРПИЧА

\title{
USE OF PETROCHEMICAL AND OIL PRODUCTION WASTE FOR EARTHQUAKE-RESISTANT BRICK MANUFACTURE
}

\section{В.3. Абдрахимов, Е.С. Абдрахимова}

Самарский государственный экономический университет, Самарский национальный исследовательский университет имени академика С.П. Королёва, г. Самара, Российская Федерация

\section{Vladimir Z. Abdrakhimov, Elena S. Abdrakhimova}

Samara State University of Economics,

Samara National Research University, Samara, Russian Federation

$$
\text { e-mail: 3375892@mail.ru }
$$

\begin{abstract}
Аннотация. Эффективная утилизация многотоннажных отходов нефтехимического производства и отходов нефтедобычи, например нефтяных шламов, - одна из актуальных экологических проблем. Неограниченными возможностями по использованию многотоннажных отходов обладает отрасль, производящая строительные материалы. В современных экономических условиях, при ограниченном государственном финансировании геологоразведочных работ, весьма важным является принятие оптимальных решений по использованию отходов для производства сейсмостойкого кирпича, которое даст максимальный социально-экономический эффект. Поскольку в настоящее время
\end{abstract}


природные сырьевые ресурсы истощены, необходимо вовлекать в производственный оборот отходы нефтехимического производства и нефтедобычи для производства строительных материалов. При этом исключаются затраты на геологоразведочные работы, строительство и эксплуатацию карьеров, освобождаются значительные земельные участки от воздействия негативных антропогенных факторов.

Опыт передовых зарубежных стран показывает техническую осуществимость этого направления, кроме того, и как инструмента защиты природной среды от загрязнения.

Цель работы - на основе бейделлитовой глины, используемой в качестве связующей высокоглиноземистого отхода нефтехимического производства - отработанного катализатора ИМ-2201, используемого в качестве отощителя, и нефтяного шлама отхода нефтедобычи, используемого в качестве выгорающей добавки, получить сейсмостойкий кирпич с высокими физико-механическими показателями. В результате получен сейсмостойкий кирпич, соответствующий маркам M150-M175. Оптимальным составом для получения сейсмостойкого кирпича является состав, содержащий отработанный катализатор ИМ $2201-21$ \% и нефтяной шлам - 7 \%. Очевидно, что дальнейшее увеличение в составах керамических масс катализатора потребует и повышение температуры обжига (более $\left.1050{ }^{\circ} \mathrm{C}\right)$, так как огнеупорность катализатора около $2000{ }^{\circ} \mathrm{C}$.

Abstract. Efficient disposal of large-tonnage waste from petrochemical production and oil production waste, such as oil sludge, is one of the pressing environmental problems. The construction materials industry has unlimited opportunities for the use of large-tonnage waste. In modern economic conditions, with limited state funding for geological exploration, it is very important to make optimal decisions on the use of waste for the production of earthquake-resistant bricks, which will give the maximum socio-economic effect. Since at present natural raw materials are depleted, it is necessary to involve petrochemical production and oil production wastes in the production turnover for the production 
of building materials. At the same time, the costs of geological exploration, construction and operation of quarries are excluded, significant land plots are freed from the impact of negative anthropogenic factors.

The experience of leading foreign countries shows the technical feasibility of this direction, in addition, as a tool for protecting the natural environment from pollution.

The aim of the work is to obtain an earthquake-resistant brick with high physical and mechanical properties on the basis of beidellite clay, used as a binder for high-alumina waste of petrochemical production - spent catalyst IM-2201, used as a weaker, and oil sludge from oil production waste, used as a burnout additive. As a result, an earthquake-resistant brick corresponding to the M150-M175 grades was obtained. The optimal composition for producing earthquake-resistant bricks is a composition containing spent catalyst IM 2201 $21 \%$ and oil sludge $-7 \%$. It is obvious that a further increase in the compositions of the ceramic masses of the catalyst will also require an increase in the firing temperature (more than $1050{ }^{\circ} \mathrm{C}$ ), since the refractoriness of the catalyst is about $2000{ }^{\circ} \mathrm{C}$.

Ключевые слова: легкоплавкая глина; нефтяной шлам; отработанный катализатор; сейсмостойкий кирпич; экология; экономика; технические показатели

Keywords: low-melting clay; oil sludge; spent catalyst; earthquake-resistant brick; ecology; economy; technical indicators

\section{Введение}

В XXI веке трудно найти более важную глобальную проблему, охватывающую всю планету, чем экологическая безопастность [1]. Поэтому все государства нашей планеты просто обязаны все свои экономические и социальные притязания привести в соответствие с ограниченными 
ресурсными возможностями природы и не пересекать ту грань, за которой возникнут необратимые процессы исчезновения человечества.

Россия обязана включиться в принятую всеми экономически развитыми странами программу перехода от линейной экономики к циркулярной или с замкнутым циклом производства, которая предусматривает переработку отходов с целью повторого их использования.

Кроме экологических проблем в России еще существуют проблемы с землятресениями. В среднем за год все подразделения Федеральное государственное бюджетное учреждения науки Федеральный исследовательский центр «Единая геофизическая служба Российской академии наук» (ФИЦ ЕГС РАН) фиксируют на территории Российской Федерации около 10 тыс. землетрясений, обеспечивая их регистрацию, начиная с магнитудного уровня $\mathrm{M}>4,0$ [2]. Количество ежегодно регистрируемых ощутимых землетрясений на территории Российской Федерации составляет около 100, из которых лишь несколько вызывают повреждения или слабые разрушения.

Для возведения самонесущих и несущих стен, согласно с п.6.14.4 СП 14.13330.2014 «Строительство в сейсмических районах», необходимо использовать керамические камни и кирпич не ниже марки M125, если сейсмичность строительной площадки выше 5 баллов $[3,4]$.

Большинство легкоплавких (кирпично-черепичных) глин Российской Федерации классифицируются как полукислые и кислые, причем неспекающиеся с высоким содержанием красящих оксидов $\left(\mathrm{Fe}_{2} \mathrm{O}_{3}>3\right.$ \%) и низким содержанием оксида алюминия $\left(\mathrm{Al}_{2} \mathrm{O}_{3}=12-18 \%\right)[3,4]$. При таком содержании оксида алюминия в глинистых компонентах из них невозможно получить кирпич марок M125 и более. Для возведения несущих стен нижних этажей зданий повышенной этажности (10 этажей и более) требуется керамический кирпич марок - M125 - M250.

К основным резервам для получения высокомарочных керамических кирпичей и камней можно отнести отходы нефтехимического производства 
с повышенным содержанием оксида алюминия $\left(\mathrm{A}_{2} \mathrm{O}_{3}>50 \%\right)$, которые можно использовать в качестве отощителей.

В настоящее время несмотря на широкий ассортимент новых строительных материалов керамический кирпич остается одним из лидеров, ведь это проверенный временем стеновой материал [4]. Из всех природных строительных материалов у керамики наименьший радиационный фон. Кирпичная стена отвечает самым высоким требованиям комфортности и износостойкости, аккумулирует тепло, благоприятно воздействует на климат жилища. Если комфортность деревянной постройки принять за 1, то комфортность помещений из керамического кирпича соответствует коэффициенту 0,7; постройки из ячеистого бетона имеют коэффициент 0,2; из силикатного кирпича и камней - 0,1-0,08; из железобетона - 0,05 [5].

\section{Задачи и исследования}

Постановка задачи. С учетом сокращения запасов традиционного природного сырья необходимо найти новые способы его замещения различными видами отходов. Опыт передовых зарубежных стран показал техническую осуществимость этого направления и применения еще и как инструмента защиты природной среды от загрязнения.

Цель. На основе бейделлитовой глины, используемой в качестве глинистой связующей, высокоглиноземистого отхода нефтехимического производства - отработанного катализатора ИМ-2201, используемого в качестве отощителя, и нефтяного шлама отхода нефтедобычи, используемого в качестве выгорающей добавки, получить сейсмостойкий кирпич с высокими физико-механическими показателями.

\section{Экспериментальная часть}

Cырьевые материальл. Для получения сейсмостойкого керамического кирпича, соответствующего марке более M125, использовались следующие сырьевые компоненты: бейделлитовая глина - в качестве глинистого 
связующего, в качестве алюмосодержащего отощителя - отработанный катализатор ИМ-2201, в качестве выгорающей добавки - нефтяной шлам. Химические составы сырьевых компонентов приведены: оксидный в таблице 1, поэлементный - в таблице 2, фракционные составы бейделлитовой глины и нефтяного шлама - в таблице 3, а технологические показатели соответственно - в таблице 4. Микроструктура сырьевых компонентов представлена на рисунке 1, а минералогический состав - на рисунке 2 .

Таблица 1. Оксидный химический состав отходов производств

\begin{tabular}{|l|c|c|c|c|c|c|c|c|}
\hline \multirow{2}{*}{ Сырьевой компонент } & \multicolumn{7}{|c|}{ Массовое содержание оксидов, \% масс. } \\
\cline { 2 - 9 } & $\mathrm{SiO}_{2}$ & $\mathrm{Al}_{2} \mathrm{O}_{3}$ & $\mathrm{Fe}_{2} \mathrm{O}_{3}$ & $\mathrm{CaO}$ & $\mathrm{MgO}$ & $\mathrm{Cr}_{2} \mathrm{O}_{3}$ & $\mathrm{R}_{2} \mathrm{O}$ & П.П.П. \\
\hline $\begin{array}{l}\text { 1. Бейделлитовая } \\
\text { глина }\end{array}$ & 46,45 & 13,14 & 5,6 & 11,13 & 2,31 & - & 4,48 & 16,89 \\
\hline $\begin{array}{l}\text { 2. Отработанный } \\
\text { катализатор }\end{array}$ & 7,90 & 74,50 & 0,15 & - & 0,10 & 14,8 & 1,58 & - \\
\hline $\begin{array}{l}\text { 3. Нефтяной шлам } \\
\text { 25,22 }\end{array}$ & 8,10 & 8,12 & 24,27 & 1,20 & - & 1,21 & 31,97 \\
\hline
\end{tabular}

Таблица 2. Поэлементный химический состав отходов производств

\begin{tabular}{|l|c|c|c|c|c|c|c|c|c|c|}
\hline \multirow{2}{*}{$\begin{array}{c}\text { Сырьевой } \\
\text { компонент }\end{array}$} & \multicolumn{7}{|c|}{ Массовое содержание элементов, \% масс. } \\
\cline { 2 - 12 } & $\mathrm{C}$ & $\mathrm{O}$ & $\mathrm{Na}$ & $\mathrm{Mg}$ & $\mathrm{Al}+\mathrm{Ti}$ & $\mathrm{Si}$ & $\mathrm{Cr}$ & $\mathrm{K}$ & $\mathrm{Ca}$ & $\mathrm{Fe}$ \\
\hline $\begin{array}{l}1 . \text { Бейделлитовая } \\
\text { глина }\end{array}$ & 4,04 & 53,12 & 0,53 & 0,54 & 14,70 & 21,19 & - & 0,73 & 0,58 & 4,57 \\
\hline $\begin{array}{l}1 . \text { Катализатор } \\
\text { ИМ-2201 }\end{array}$ & - & 60,74 & 1,0 & - & 26,58 & 2,82 & 8,1 & 1,80 & - & 0,01 \\
\hline $\begin{array}{l}\text { 2. Нефтяной } \\
\text { шлам Самарской } \\
\text { области }\end{array}$ & $\begin{array}{c}16,0 \\
2\end{array}$ & 44,03 & 0,83 & 0,87 & 5,14 & 5,49 & & 0,89 & 22,58 & 4,15 \\
\hline
\end{tabular}

Таблица 3. Фракционный состав бейделлитовой глины и нефтяного шлама

\begin{tabular}{|l|c|c|c|c|c|}
\hline \multicolumn{1}{|c|}{$\begin{array}{c}\text { Сырьевой } \\
\text { компонент }\end{array}$} & \multicolumn{5}{|c|}{ Содержание фракций в \%, размер частиц в мм } \\
\cline { 1 - 6 } & $>0,063$ & $0,063-0,01$ & $0,01-0,005$ & $0,005-0,001$ & $<0,0001$ \\
\hline $\begin{array}{l}\text { 1. Бейделлитовая } \\
\text { глина }\end{array}$ & 7 & 8 & 11 & 19 & 55 \\
\hline $\begin{array}{l}\text { 2. Нефтяной шлам } \\
\text { Самарской области }\end{array}$ & 13,5 & 14,3 & 14,8 & 20,1 & 37,4 \\
\hline
\end{tabular}


Таблица 4. Технологические показатели бейделлитовой глины и нефтяного шлама

\begin{tabular}{|l|c|c|c|c|}
\hline \multirow{2}{*}{ Сырьевой компонент } & \multirow{2}{*}{\begin{tabular}{c} 
Теплотворная \\
способность, \\
\cline { 3 - 5 }
\end{tabular}} & $\begin{array}{c}\text { нкал/кг } \\
\text { кефоло }\end{array}$ & $\begin{array}{c}\text { размяг- } \\
\text { чение }\end{array}$ & $\begin{array}{c}\text { жидкоплавкое } \\
\text { состояние }\end{array}$ \\
\hline 1. Бейделлитовая глина & 450 & 1280 & 1300 & 13540 \\
\hline $\begin{array}{l}2 . \text { Нефтяной шлам } \\
\text { Самарской области }\end{array}$ & 3300 & 1850 & 1280 & 1290 \\
\hline
\end{tabular}

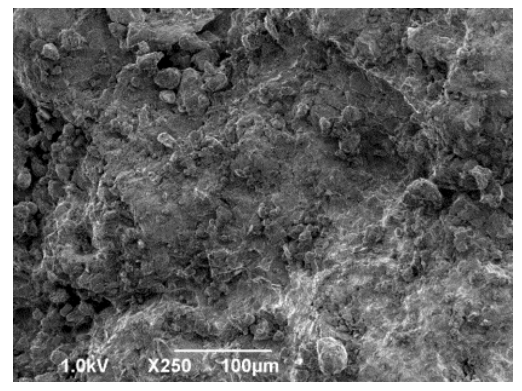

a)

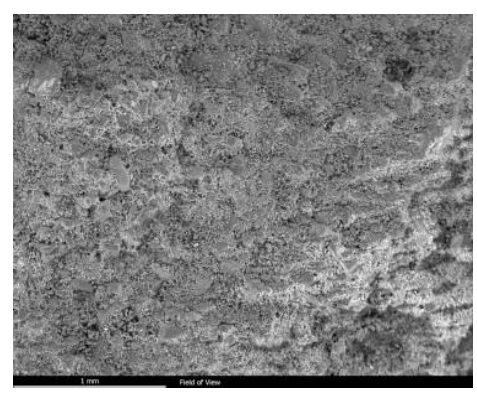

б)

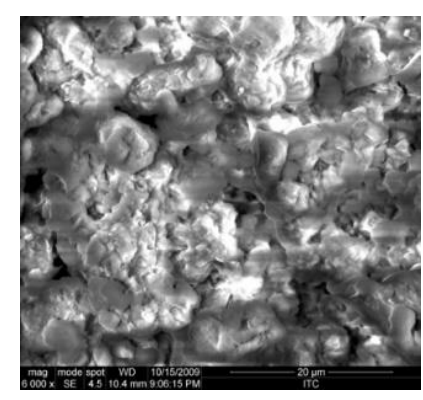

B)

а) бейделлитовая глина;

б) отработанный катализатор;

в) нефтяной шлам

Рисунок 1. Микроструктура исследуемых сырьевых материалов (увеличение: а) и б) в 250 раз, в) в 6000 раз)

Легкоплавкая бейделлитовая глина. Глина применяется в качестве основного глинистого сырья для производства керамического кирпича на Тольяттинских кирпичных заводах. Бейделлитовая глина Образцовского месторождения, характеризуемая как среднедисперсная, преимущественно с низким содержанием мелких и средних включений, представленных кварцем, железистыми минералами, гипсом и карбонатными включениями $[6,7]$. Основным породообразующим минералом образцовской глины является бейделлит - $\mathrm{Al}_{2}\left[\mathrm{Si}_{4} \mathrm{O}_{10}\right][\mathrm{OH}]_{2} \cdot \mathrm{nH}_{2} \mathrm{O}$, названный по местности Бейделл штата Колорадо (США) и относящийся к минералам группы монтмориллонита [7].

Глина Образцовского месторождения по гранулометрическому составу относится к группе среднедисперсного сырья, высокочувствительная к сушке, характеризуется высокой усадкой образцов. По пластичности, а ее 
число пластичности 15-21, глину можно идентифицировать как среднепластичную. Огнеупорность глины 1300-1320 으 (легкоплавкая), число пластичности 18-20 (среднепластичная), содержание тонкодисперсных фракций размером менее 1 мкм 40-60 \% (дисперсное).

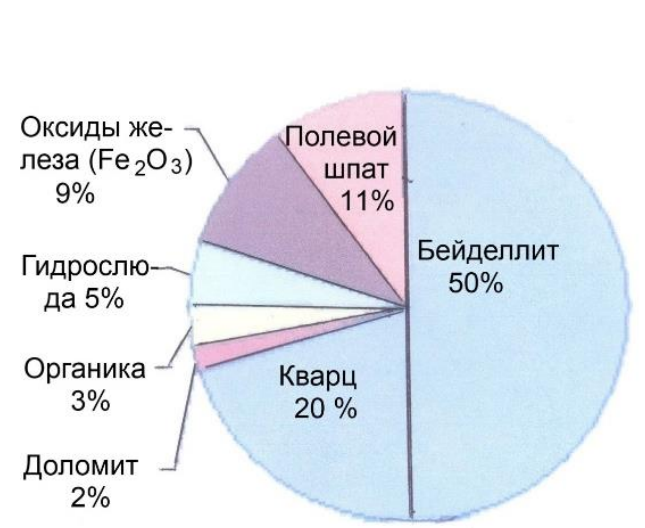

a)

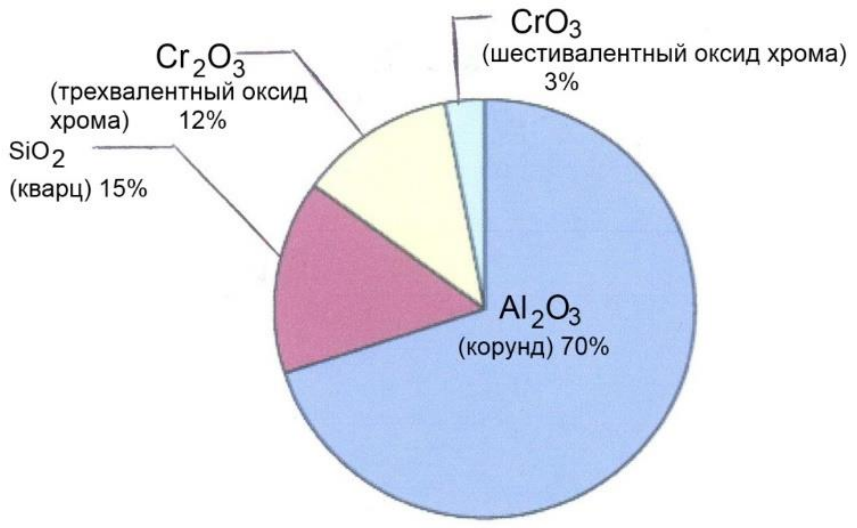

б)

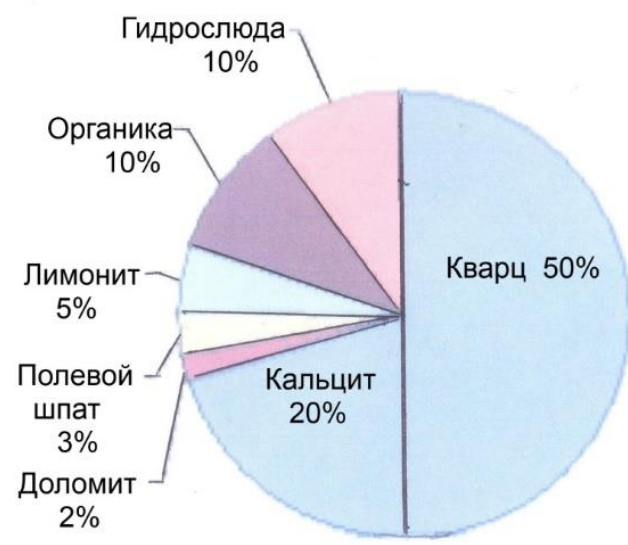

в)

а) бейделлитовая глина;

б) отработанный катализатор ИМ-2201;

в) нефтяной шлам

Рисунок 2. Минералогические составы сырьевых компонентов

На рисунке 3 из образцовской глины без добавок представлен кирпич, обожженный на кирпичном заводе города Тольятти в туннельной печи при температуре обжига $1000^{\circ} \mathrm{C}$. 


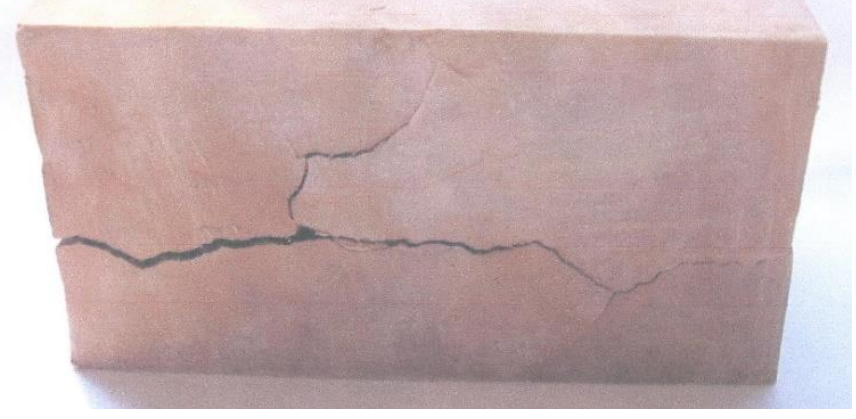

Рисунок 3. Полнотелый кирпич из образцовской глины, обожженный при температуре $1000{ }^{\circ} \mathrm{C}$

Как видно из рисунка 3, обожженный кирпич из образцовской глины имеет глубокую трещину и сильно деформирован. Минерал бейделлит, как и минерал монтмориллонит относятся к минералам, которые вспучиваются при обжиге. Таким образом, для получения сейсмостойкого кирпича необходимо в составы керамических масс вводить отощители. Как показывают исследования, благодаря использованию высокоглиноземистого нанотехногенного отработанного катализатора ИМ-2201 на основе бейделлитовой глины можно получить высококачественный сейсмостойкий кирпич.

Отработанный катализатор ИМ-2201. Для получения сейсмостойкого кирпича отработанный катализатор использовался в качестве отощителя. Для уменьшения усадки в процессе сушки вводят отощающие материалы отощители. Они уменьшают пластичность, облегчают сушку и повышают прочность.

Почти 90 \% химических процессов требуют применения катализаторов. Учитывая тот факт, что для протекания различных реакций требуются соответственные катализаторы, сегодня на рынке существует более тысячи наименований марок этого наукоемкого продукта. К таким процессам относятся и процессы нефтепереработки, на долю которых приходится около 35-40 \% от всех применяемых в России катализаторов. Но в настоящее время несмотря на появление катализаторных производств 
российский рынок сильно зависим от зарубежных катализаторов, что ставит вопрос импортозамещения в ряд наиболее актуальных.

Отработанный катализатор ИМ-2201 является нанотехногенным отходом нефтехимического производства Акционерного общества «Новокуйбышевская нефтехимическая компания» (АО «ННК») и представляет собой дисперсионный скомкавшийся порошок (рисунок $1, \sigma$ ) с удельной поверхностью до $8000 \mathrm{~cm}^{2} /$, с числом пластичности 9-11, огнеупорность которого может достигать $2000^{\circ} \mathrm{C}$.

Как видно из таблицы 1 , содержание $\mathrm{A}_{2} \mathrm{O}_{3}$ в нанотехногенном катализаторе составляет $74,5 \%$. Авторы работ $[8,9]$ считают, что $\mathrm{Al}_{2} \mathrm{O}_{3}$ в составе неметаллических материалов чаще всего встречается в качестве высокотемпературной $\alpha$-модификации, являющейся аналогом природного минерала корунда, который имеет высокую температуру плавления $2050{ }^{\circ} \mathrm{C}$. Хотя низкотемпературная $\gamma$-модификация $\mathrm{A}_{2} \mathrm{O}_{3}$ может перейти $\alpha$-модификацию уже при температурах, начиная с $1050{ }^{\circ} \mathrm{C}$. Исследуемое нанотехногенное сырье отличается от высокодисперсных порошкообразных материалов как техногенного, так и природного происхождения наноразмерностью. Наноразмерность отработанного катализатора колеблется в пределах от 100 до 3000 нм в зависимости от условий образования.

Исследования проб нанотехногенного отработанного катализатора ИМ-2201 для измерения размерности частиц катализатора были проведены в Научно-исследовательском институте ядерных исследований (г. Гатчина, Ленинградская область) с помощью метода малоуглового рассеяния нейтронов на дифрактометре «Мембрана-2» [9].

Нефтяной шлам Самарской области. В данной работе был использован нефтяной шлам (кек), образующийся на нефтедобывающем предприятии в г. Нефтегорск и представляющий собой мелкодисперсный порошок тёмнокоричневого цвета (рисунок 1, в). Нефтяной шлам (кек) - это твердый нефтесодержащий отход сепарации нефтешлама, который использовался в 
качестве выгорающей добавки. Как видно из рисунка 2, в, содержание в нефтяном шламе органики, которая в основанном представлена нефтяными продуктами, 10 \%. Химические составы исследуемых отходов представлены: оксидный - в таблице 1, поэлементный - в таблице 2, фракционный состав - в таблице 3, а технологические показатели представлены в таблице 4.

В таблице 5 представлен компонентный состав нефтяной части исследуемого нефтяного шлама.

Таблица 5. Компонентный состав нефтяной части нефтяного шлама

\begin{tabular}{|l|c|}
\hline \multicolumn{1}{|c|}{ Наименование веществ } & Содержание, \% масс. \\
\hline Смолы & 5,3 \\
\hline Асфальтены & 5,3 \\
\hline Парафины & 9,0 \\
\hline Тяжёлые масла & 80,4 \\
\hline
\end{tabular}

Авторы работы [10] показали, что опасными являются глобальные потоки углеводородов (УВ) нефтяных шламов, которые проникают в почву. Проникшие в почву потоки образуют определенный комплекс УВ различных классов, которые могут находиться в трех агрегатных состояниях, что неблагоприятно влияет на фауну и флору данной территории региона. Образовавшийся комплекс нефтяных УВ очень сложен по составу и содержит тысячи индивидуальных компонентов, которые различны по физическим, химическим и токсикологическим свойствам [11$13]$.

Содержащиеся в нефтяных шламах тяжелые фракции, как правило, малоподвижны и создают устойчивые очаги загрязнения, очищение природной среды от них протекают медленно и с большим трудом. Многочисленные исследования в работах [10, 12-14] показали, что в нефтяной части нефтяного шлама повышенное содержание тяжелых фракций (от 70 \% до 85 \%, в основным тяжелых масел), которые оказывают 
не только токсичное воздействие на организмы, но и значительно изменяют водно-физические свойства почв. Тяжелые фракции ухудшают воднофизические свойства почв из-за цементации порового почвенного пространства [10, 14-16].

Смолы, асфальтены и суммарные нефтяные углеводороды в западной технической литературе рассматриваются и считаются сложным комплексом разнообразных веществ, входящих в цепочные и циклические молекулы УВ - гетероатомные соединения и высокомолекулярные поликонденсационные соединения [10, 16-18]. Асфальтены и смолы, как и тяжелые масла ухудшают водно-физические свойства почв из-за цементации порового почвенного пространства.

Исследования, поведенные в работе [10], показали, что низко- $\left(\mathrm{C}_{10}-\mathrm{C}_{16}\right)$ и высокомолекулярные $\left(\mathrm{C}_{16}-\mathrm{C}_{34}\right)$ нефтяные УВ необходимо исследовать отдельно, так как в нефтяной части нефтяного шлама до 10 \% составляют парафины. Попадание парафиновой составляющей нефти в почву ведет к нарушению (причем на долгий срок) влагообмена почвы. Такой влагообмен очень опасен для почвы, так как, имея низкую температуру застывания, прочно закупоривают поры и каналы почвы, по которым происходит обмен веществ между почвой и сопредельными средами.

Таким образом, за счет повышенных содержаний в нефтяном шламе органики (п.п.п. = 31,97 \%, таблица 1$)$, углерода $(\mathrm{C}=16,2$ \%, таблица 2) и теплотворной способности $\left(\theta_{\mathrm{p}}{ }^{\mathrm{H}}=3300\right.$ кал/кг, таблица 4), которые выгорают или способствуют выгоранию (теплотворная способность) при обжиге, в керамическом материале создается пористость, способствующая выходу газов. Выгорающие добавки повышают температуру внутри кирпича, снижают расход топлива, повышают пористость и уменьшают вес готовых изделий. 


\section{Технология получения сейсмостойкого кирпича}

Сырьевые материалы предварительно высушивались до влажности не более 5 \%, затем измельчались до прохождения сквозь сито 1,0 мм. Высушенные и измельченные сырьевые материалы тщательно перемешивали. Керамическую массу готовили пластическим способом при влажности 20-24 \% (в зависимости от содержания глинистого компонента), из которой формовали кирпич. Кирпич-сырец высушивали до влажности не более 5-6 \% и затем обжигали при температуре 1050 $\mathrm{C}$. Изотермическая выдержка при конечной температуре составляла 60 мин. В таблице 6 приведены составы керамических масс, а физико-механические показатели сейсмостойкого кирпича - в таблице 7.

Таблица 6. Составы керамических масс

\begin{tabular}{|l|c|c|c|}
\hline \multicolumn{1}{|c|}{ Компонент } & 1 & 2 & 3 \\
\hline 1. Бейделлитовая глина & 80 & 70 & 60 \\
\hline 2. Катализатор ИМ-2201 & 15 & 21 & 28 \\
\hline 3. Нефтяной шлам Самарской области & 5 & 7 & 12 \\
\hline
\end{tabular}

Таблица 7. Физико-механические показатели кирпича

\begin{tabular}{|c|c|c|c|}
\hline \multirow{2}{*}{ Показатели } & \multicolumn{3}{|c|}{ Составы } \\
\hline & 1 & 2 & 3 \\
\hline $\begin{array}{l}\text { Пластичность шихты } \\
\text { величина) }\end{array}$ & 16 & 15 & 11 \\
\hline Время сушки кирпича, ч & 65 & 58 & 48 \\
\hline Усадка высушенного кирпича, \% & 5,8 & 5,2 & 4,7 \\
\hline Плотность, кг $/ \mathrm{M}^{3}$ & 1640 & 1650 & 1680 \\
\hline Морозостойкость, циклы & 48 & 52 & 55 \\
\hline $\begin{array}{l}\text { Механическая прочность на сжатие, } \\
\text { МПа }\end{array}$ & 16,7 & 17,9 & 17,2 \\
\hline $\begin{array}{l}\text { Механическая прочность при изгибе, } \\
\text { МПа }\end{array}$ & 3,6 & 3,9 & 3,7 \\
\hline Теплопроводность, Вт/(мº $\mathrm{C})$ & 0,48 & 0,50 & 0,57 \\
\hline Общая усадка, \% & 6,1 & 5,6 & 5,0 \\
\hline Открытая пористость, \% & 26 & 24 & 22 \\
\hline
\end{tabular}


На рисунке 4 показана микроструктура образца из оптимального состава № 2 (увеличение в 1000 раз). На представленном рисунке отчетливо видна открытая пористость.

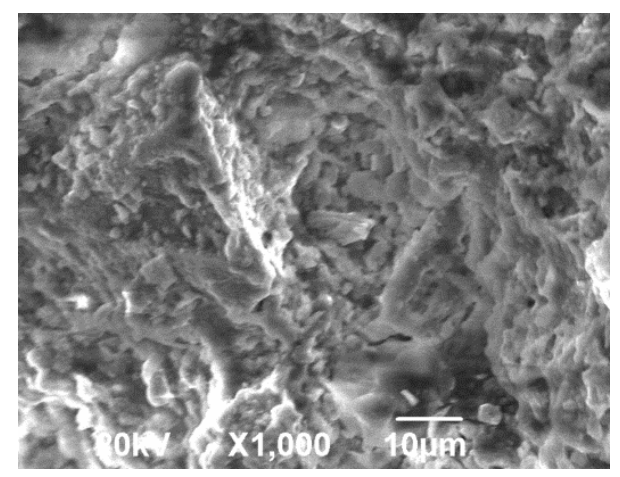

Рисунок 4. Микроструктура образца из оптимального состава № 2

\section{Обсуждение результатов}

Как видно из таблицы 5, образцы всех трех исследуемых составов можно отнести к сейсмостойким стеновым материалам, так как они имеют марку более М125. Образцы из составов № 1 и № 3 имеют марку M125, а образцы из состава № 2 - марку М175, поэтому состав № 2, содержащий отработанный катализатор ИМ-2201, - 21 \%, а нефтяной шлам - 7 \%, является оптимальным. Очевидно, что дальнейшее увеличение в составах керамических масс отработанного катализатора ИМ-2201 потребует и повышение температуры обжига (более $1050{ }^{\circ} \mathrm{C}$ ), так как огнеупорность катализатора - около $2000{ }^{\circ} \mathrm{C}$.

Обычно плотность сплошного керамического кирпича колеблется в

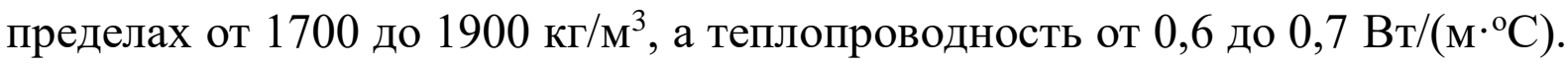
Стены, выложенные из такого полнотелого стенового материала, нуждаются в добавочном утеплении. Образцы (полнотелые) исследуемых

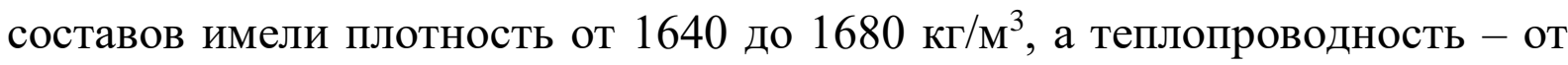
0,48 до $0,57 \mathrm{BT} /\left(\mathrm{M}^{\circ}{ }^{\circ} \mathrm{C}\right)$. По-видимому, это связано с повышенным содержанием в нефтяном шламе теплотворной способности (3300 ккал/кг, таблица 4), органики (п.п.п. = 31,97 \%, таблица 1$)$ и углерода $(\mathrm{C}=16,02 \%$, таблица 2). 
Повышенные содержания в нефтяном шламе органических веществ, углерода и высокая теплотворность способствуют увеличению температуры внутри кирпича, снижают расход топлива, увеличивают пористость и уменьшают вес готовых изделий. При выгорании органической добавки выделяется небольшое количество сопутствующих газов, что приводит к уплотнению стенок вокруг каждой частички, а в итоге повышает прочность всего изделия [19].

В исследуемом образце состава № 2 чаще всего встречаются поры трех типов: щелевидные, изометрические и поры, используя терминологию автора работы [19], причудливой формы.

Кроме того, в образце № 2 (рисунок 4) присутствуют сравнительно крупные поры (до 35 мкм) овальной формы и изометричные поры типа «каналов». Именно эти поры, как считает автор работ [19], определяют водопоглощение керамических материалов.

Состав № 2 считается оптимальным (таблица 7) по физикомеханическим показателям. Наличие пор изометрической формы и овальной закрытой пористости в пористом заполнителе придают ему механическую прочность [19].

\section{Выводы}

1. Использование отработанного катализатора ИМ-2201 и нефтяного шлама в производстве сейсмостойкого кирпича на основе бейделлитовой глины позволяет получать стеновой материал (кирпич) марки М150-M175, что позволит строить жилые дома более 10 этажей.

2. Оптимальным составом для получения сейсмостойкого кирпича является состав № 2, содержащий отработанный катализатор ИМ-2201 $21 \%$, а нефтяной шлам - $7 \%$. Очевидно, что дальнейшее увеличение в составах керамических масс отработанного катализатора ИМ-2201 потребует и повышение температуры обжига (более $1050{ }^{\circ} \mathrm{C}$ ), так как огнеупорность катализатора около $2000{ }^{\circ} \mathrm{C}$. 
3. Повышенные содержания органических веществ, углерода и высокая теплотворность в нефтяном шламе позволяют повысить температуру внутри кирпича, снизить расход топлива, повысить пористость и уменьшить вес готовых изделий. При выгорании органической добавки выделяется небольшое количество сопутствующих газов, что приводит к уплотнению стенок вокруг каждой частички, а в итоге повышает прочность всего изделия.

4. Безусловным достоинством использования многотоннажных отходов нефтехимического производства и отходов нефтедобычи является разгрузка экологической обстановки, поскольку способствует решению следующих задач:

а) утилизация промышленных отходов и техногенных отложений, что способствует охране окружающей среды;

б) учитывая, что в настоящее время природные сырьевые ресурсы истощены, способствует вовлечению техногенных образований в производственный оборот для производства строительных материалов;

в) освобождение значительных земельных участков от воздействия негативных антропогенных факторов и рациональное использование ингредиентов промышленных отвалов для объектов стройиндустрии;

г) снижение стоимости строительных материалов;

д) рациональное природопользование за счет вовлечения отходов в производство керамических материалов;

е) исключение затрат на геологоразведочные работы, на строительство и эксплуатацию карьеров.

\section{Список используемых источников}

1. Абдрахимов В.З., Кайракбаев А.К. Экологический менеджмент. Актобе: Учреждение Актюбинский университет имени академика С. Баишева, 2019. 240 с. 
2. Маловичко А.А., Селезнев В.С., Виноградов Ю.Н., Дягилев Р.А., Горажаев С.В. Федеральный исследовательский центр Единая геофизическая служба Российской академии наук. Обнинск: ФИЦ ЕГС PAH, 2017. $51 \mathrm{c}$.

3. Абдрахимов В.3. Влияние нанотехногенного сырья на сушильные свойства и физико-механические показатели керамического кирпича // Сейсмостойкое строительство. Безопасность сооружений. 2020. № 1. C. 29-34.

4. Абдрахимов В.З. Использование обожженного солевого шлака для получения высокопрочного сейсмологического кирпича // Сейсмостойкое строительство. Безопасность сооружений. 2019. № 5. С. 45-50.

5. Сайбулатов С.Ж., Сулейменов С.Т., Ралко А.В. Золокерамические стеновые материалы. Алма-Ата: Наука, 1982. 291 с.

6. Салахов А.М., Ремизникова В.И., Спирина О.В., Мочалов А.Ю. Производство строительной керамики. Казань: Центр инновационных технологий, 2003. 292 с.

7. Шевандо В.В., Абдрахимов А.В., Вдовина Е.В., Абдрахимов В.З., Абдрахимова Е.С. Использование золошлакового материала на основе бейделлитовой глины в производстве керамического кирпича // Промышленное и гражданское строительство. 2008. № 10. С. 46-47.

8. Литвинова Т.И., Пирожкова В.П., Петров А.К. Петрография неметаллических включений. М.: Металлургия, 1972. 184 с.

9. Хлыстов А.И., Соколова С.В., Власов А.В. Повышение эффективности жаростойких композитов за счет применения химических связующих // Строительные материалы, оборудование, технологии XXI века. 2012. № 9 (164). С. 38-42.

10. Геннадиев А.Н., Пиковский Ю.И., Цибарт А.С., Смирнова М.А. Углеводороды в почвах: происхождение, состав, поведение (обзор) // Почвоведение. 2015. № 10. С. 1195-1209. DOI: 10.7868/S0032180X15100020. 
11. Mao D., Lookman R., Van de Weghe H., Weltens R., Vanermen G., De Brucker N., Dies L. Estimation of Ecotoxicity of Petroleum Hydrocarbon Mixtures in Soilbased on HPLC-GCXGC Analysis // Chemosphere. 2009. Vol. 77. Issue 11. P. 1508-1513. DOI: 10.1016/j.chemosphere.2009.10.004.

12. Tang J., Lu X., Sum Q., Zhu W. Aging Effect of Petroleum Hydrocarbons in Soil Under Different Attenuation Conditions // Agriculture, Ecosystems and Environment. 2012. Vol. 149. P. 109-117. DOI: 10.1016/j.agee.2011.12.020.

13. Chang W., Dyen M., Spagnuolo L., Simon P., Whyte L., Ghoshal S. Biodegradation of Semi- and Non-Volatile Petroleum Hydrocarbons in Aged, Contaminated Soils from a Sub-Arctic Site: Laboratory Pilot-Scale Experiment at Site Temperatures // Chemosphere. 2010. Vol. 80. Issue 3. P. 319-326. DOI: 10.1016/j.chemosphere.2010.03.055.

14. Pinedo J., Ibbez R., Lizen J.P.A., Irabien A. Human Risk Assessment of Contaminated Soils by Oil Products: Total TPH Content Versus Fraction Approach // Human and Ecological Risk Assessment. 2014. Vol. 20. Issue 5. P. 1231-1248. DOI: 10.1080/10807039.2013.831264.

15. Barnes D.L., Chuvilin E. Migration of Petroleum in Permafrost-Affected Regions // Permafrost Soils: In Book. Berlin: Springer Berlin Heidelberg, 2009. Vol. 16. P. 263-278. DOI: 10.1007/978-3-540-69371-0_18.

16. Liu P.G., Chang T.Ch., Chen Ch.-H., Wang M.-Zh., Hsu H.-W Effects of Soil Organic Matter and Bacterial Community Shift on Bioremediation of DieselContaminated Soil // International Biodeterioration and Biodegradation. 2013. Vol. 85. P. 661-670. DOI: 10.1016/j.ibiod.2013.01.010.

17. Wu G., Zhu X., Ji H., Chen D. Molecular Modeling of Interactions Between Heavy Crude Oil and the Soil Organic Matter Coated Quartz Surface // $\begin{array}{llllll}\text { Chemosphere. 2015. Vol. 119. P. 242-249. DOI: } & \text { P. }\end{array}$ 10.1016/j.chemosphere.2014.06.030. 
18. Huesemann M.H., Hausmann T.S., Fortman T.J. Does Bioavailability Limit Biodegradation? A Comparison of Hydrocarbon Biodegradation and Desorption Rates in Aged Soils // Biodegradation. 2014. Vol. 15. Issue 4. P. 261-274. DOI: 10.1023/b:biod.0000042996.03551.f4.

19. Павлов В.Ф. Физико-химические основы обжига изделий строительной керамики. М.: Стройиздат, 1977. 240 с.

\section{References}

1. Abdrakhimov V.Z., Kairakbaev A.K. Ekologicheskii menedzhment [Environmental Management]. Aktobe, Uchrezhdenie Aktyubinskii universitet imeni akademika S. Baisheva Publ., 2019. 240 p. [in Russian].

2. Malovichko A.A., Seleznev V.S., Vinogradov Yu.N., Dyagilev R.A., Gorazhaev S.V. Federal'nyi issledovatel'skii tsentr Edinaya geofizicheskaya sluzhba Rossiiskoi akademii nauk [Federal Research Center Unified Geophysical Service of the Russian Academy of Sciences]. Obninsk, FITs EGS RAN Publ., 2017. 51 p. [in Russian].

3. Abdrakhimov V.Z. Vliyanie nanotekhnogennogo syr'ya na sushil'nye svoistva i fiziko-mekhanicheskie pokazateli keramicheskogo kirpicha [The Influence of Nanotechnogenic Raw Materials on the Drying Properties and Physical and Mechanical Properties of Ceramic Bricks]. Seismostoikoe stroitel'stvo. Bezopasnost' sooruzhenii - Earthquake Engineering. Constructions Safety, 2020, No. 1, pp. 29-34. [in Russian].

4. Abdrakhimov V.Z. Ispol'zovanie obozhzhennogo solevogo shlaka dlya polucheniya vysokoprochnogo seismologicheskogo kirpicha [The Use of Annealed Aluminum Salt Slag to Obtain a High Strength Antiseismic Brick]. Seismostoikoe stroitel'stvo. Bezopasnost' sooruzhenii-Earthquake Engineering. Constructions Safety, 2019, No. 5, pp. 45-50. [in Russian].

5. Saibulatov S.Zh., Suleimenov S.T., Ralko A.V. Zolokeramicheskie stenovye materialy [Ceramic Wall Materials]. Alma-Ata, Nauka Publ., 1982. 291 p. [in Russian]. 
6. Salakhov A.M., Remiznikova V.I., Spirina O.V., Mochalov A.Yu. Proizvodstvo stroitel'noi keramiki [Building Ceramics Production]. Kazan, Tsentr innovatsionnykh tekhnologii Publ., 2003. 292 p. [in Russian].

7. Shevando V.V., Abdrakhimov A.V., Vdovina E.V., Abdrakhimov V.Z., Abdrakhimova E.S. Ispol'zovanie zoloshlakovogo materiala na osnove beidellitovoi gliny v proizvodstve keramicheskogo kirpicha [The Use of Ash-Slag Material on the Basis of Beaydelyt Clay for Production of Ceramic Bricks]. Promyshlennoe i grazhdanskoe stroitel'stvo - Industrial and Civil Engineering, 2008, No. 10, pp. 46-47. [in Russian].

8. Litvinova T.I., Pirozhkova V.P., Petrov A.K. Petrografiya nemetallicheskikh vklyuchenii [Petrography of Non-Metallic Inclusions]. Moscow, Metallurgiya Publ., 1972. 184 p. [in Russian].

9. Khlystov A.I., Sokolova S.V., Vlasov A.V. Povyshenie effektivnosti zharostoikikh kompozitov za schet primeneniya khimicheskikh svyazuyushchikh [Increase of Efficiency of Heat-Resistant Composites Through the Use of Chemical Binders]. Stroitel'nye materialy, oborudovanie, tekhnologii XXI vekaBuilding Materials, Equipment, Technologies of the XXI Century, 2012, No. 9 (164), pp. 38-42. [in Russian].

10. Gennadiev A.N., Pikovskii Yu.I., Tsibart A.S., Smirnova M.A. Uglevodorody $\mathrm{v}$ pochvakh: proiskhozhdenie, sostav, povedenie (obzor) [Hydrocarbons in Soils: Origin, Composition, and Behavior (Review)]. Pochvovedenie - Pochvovedenie, 2015, No. 10, pp. 1195-1209. DOI: 10.7868/S0032180X15100020. [in Russian].

11. Mao D., Lookman R., Van de Weghe H., Weltens R., Vanermen G., De Brucker N., Dies L. Estimation of Ecotoxicity of Petroleum Hydrocarbon Mixtures in Soilbased on HPLC-GCXGC Analysis. Chemosphere, 2009, Vol. 77, Issue 11, pp. 1508-1513. DOI: 10.1016/j.chemosphere.2009.10.004.

12. Tang J., Lu X., Sum Q., Zhu W. Aging Effect of Petroleum Hydrocarbons in Soil Under Different Attenuation Conditions. Agriculture, Ecosystems and Environment, 2012, Vol. 149, pp. 109-117. DOI: 10.1016/j.agee.2011.12.020. 
13. Chang W., Dyen M., Spagnuolo L., Simon P., Whyte L., Ghoshal S. Biodegradation of Semi- and Non-Volatile Petroleum Hydrocarbons in Aged, Contaminated Soils from a Sub-Arctic Site: Laboratory Pilot-Scale Experiment at Site Temperatures. Chemosphere, 2010, Vol. 80, Issue 3, pp. 319-326. DOI: 10.1016/j.chemosphere.2010.03.055.

14. Pinedo J., Ibbez R., Lizen J.P.A., Irabien A. Human Risk Assessment of Contaminated Soils by Oil Products: Total TPH Content Versus Fraction Approach. Human and Ecological Risk Assessment, 2014, Vol. 20, Issue 5, pp. 1231-1248. DOI: 10.1080/10807039.2013.831264.

15. Barnes D.L., Chuvilin E. Migration of Petroleum in Permafrost-Affected Regions. In Book «Permafrost Soils». Berlin, Springer Berlin Heidelberg, 2009, Vol. 16, pp. 263-278. DOI: 10.1007/978-3-540-69371-0_18.

16. Liu P.G., Chang T.Ch., Chen Ch.-H., Wang M.-Zh., Hsu H.-W Effects of Soil Organic Matter and Bacterial Community Shift on Bioremediation of DieselContaminated Soil. International Biodeterioration and Biodegradation, 2013, Vol. 85, pp. 661-670. DOI: 10.1016/j.ibiod.2013.01.010.

17. Wu G., Zhu X., Ji H., Chen D. Molecular Modeling of Interactions Between Heavy Crude Oil and the Soil Organic Matter Coated Quartz Surface. Chemosphere, 2015, Vol. 119, pp. 242-249. DOI: 10.1016/j.chemosphere.2014.06.030.

18. Huesemann M.H., Hausmann T.S., Fortman T.J. Does Bioavailability Limit Biodegradation? A Comparison of Hydrocarbon Biodegradation and Desorption Rates in Aged Soils. Biodegradation, 2014, Vol. 15, Issue 4, pp. 261274. DOI: 10.1023/b:biod.0000042996.03551.f4.

19. Pavlov V.F. Fiziko-khimicheskie osnovy obzhiga izdelii stroitel'noi keramiki [Physicochemical Fundamentals of Firing Building Ceramics]. Moscow, Stroiizdat Publ., 1977. 240 p. [in Russian]. 


\section{Сведения об авторах}

\section{About the authors}

Абдрахимов Владимир Закирович, доктор технических наук, профессор кафедры «Землеустройство и кадастры», Самарский государственный экономический университет, г. Самара, Российская Федерация

Vladimir Z. Abdrakhimov, Doctor of Engineering Sciences, Professor of Land Management and Cadastre Department, Samara State University of Economics, Samara, Russian Federation

e-mail: 3375892@mail.ru

Абдрахимова Елена Сергеевна, кандидат технических наук, доцент кафедры «Химия», Самарский национальный исследовательский университет имени. академика С.П. Королева, г. Самара, Российская Федерация

Elena S. Abdrakhimova, Candidate of Engineering Sciences, Assistant Professor of Chemistry Department, Samara National Research University, Samara, Russian Federation

e-mail: 3375892@mail.ru 